\title{
Children's School Achievement and Parental Work: an analysis for Sweden
}

\section{Magdalena Norberg-Schönfeldt}

\begin{abstract}
In this paper, data from Statistics Sweden about students entering upper secondary school $\left(10^{\text {th }}\right.$ grade) in 1994 and graduating in 1996 or 1997, along with socioeconomic characteristics from the 1990 census, are used to explore the relationship between the market work by mothers and fathers in Sweden and their children's educational achievement, measured as Grade Point Average. The results show, in line with previous research, that there is a positive relationship between parental income and child GPA. When it comes to the number of hours of work that the parents perform in the labour market, the results differ between mothers and fathers. If the mother works less then full time, preferably even less then halftime, it has positive effects on the child's grades. There are no significant effects of the father's hours of work, as long as he works a positive amount of time. The lack of effects from the father's hours of work may, however, be due to lack of variation in data.
\end{abstract}

JEL classification: D10; I20; J22

Key words: Time allocation; labour-force participation; educational achievements; child GPA 
During the past twenty years, researchers in social sciences have been trying to find explanations to why some children succeed in life while others do not. The research has generated a number of theories and hypotheses regarding parental characteristics and their influences on children's success, measuring the degree of success in several different ways, educational performance being the outcome variable most widely used. The purpose of this paper is to explore the relationship between the market work by mothers and fathers in Sweden and their children's educational achievement, measured as Grade Point Average, while controlling for a wide range of other socioeconomic variables.

One of the hypotheses that has gained a lot of attention in previous research is the "working mother hypothesis" 1 where the labour force participation by mothers is said to have two offsetting effects. The mother working and contributing to family income may have a positive effect on the child's future success. At the same time, the mother's absence from home may have a negative impact on the child's development. One of the reasons why it is interesting to do this type of research using Swedish data is that Sweden, since the mid-1960s, has had a high quality child care system, which has encouraged the labour market activities of women. Seen in the light of the working mother hypothesis, it is not obvious that such a policy would have solely positive effects in the long run. Also, it is not obvious that only the hours worked by mothers should matter, labour force participation by fathers might be of importance as well. Previous studies have not included data on fathers' labour force participation.

Among the studies focusing on school achievement as dependent variable, the centre of attention has been on a variety of socioeconomic factors and parental characteristics. In these studies parental income generally has been found to have a strong positive effect. Parental education and occupational status are also found to have positive and significant effects on children's educational achievements. ${ }^{2}$ The educational level of the mother has often been found to be more highly correlated

\footnotetext{
${ }^{1}$ The hypothesis is first mentioned by Haveman, Wolfe and Spaulding (1991). Hetherington, Camara and Featherman (1983) found results consistent with the hypothesis.

${ }^{2}$ See Hill and Duncan (1987) for a review.
} 
with the educational achievements of the child than has the fathers' educational level. The explanation is thought to be that mothers usually spend more time with their children than fathers do. ${ }^{3}$ Growing up in a single parent household seems to have a negative impact on outcomes, so has the number of siblings if you are not the eldest. ${ }^{4}$ The number of regional moves by the family and the number of school moves by the student are also associated with poor academic performance. Pribesh and Downey (1999) find that this result is partially due the decline in social relationships by students who move, but that pre-existing differences between the movers and the nonmovers captures most of the effect. Other variables found to be of importance are for instance gender, race and religion of the child.

When it comes to testing for the influence of mothers' work on children's educational achievement, the results are inconsistent. Murnane, Maynard and Ohls (1981) find no evidence that children in low income families whose mothers work outside the home achieve less in school than children whose mothers do not work outside the home. Leibowitz (1977) finds the same result for middle-class families. Both these studies indicate that mothers who work outside the home decrease their time spent on housework, but that they do not substantially decrease their time spent with their children. Stafford (1986) finds a significant and negative effect of mothers' market work on the teacher's ratings of the child. For children aged 12-15, Haveman, Wolfe and Spaulding (1991) instead find a positive relation between mothers working and the child's performance in school.

Instead of testing for the influence of mothers' work on children's school achievement in terms of grades, Datcher-Loury (1988) focused on the time spent on child care by mothers and its effect on children's years of schooling. She finds that higher maternal home production increases child care time, but that child care time decreases with higher opportunity costs of home time. Children's years of schooling rises significantly with maternal child care time.

Socioeconomic background is not the only thing taken into consideration in the literature of children's educational achievements. School specific variables such as

\footnotetext{
${ }^{3}$ See Leibowitz (1974) and Hill and Stafford (1980).

${ }^{4}$ See McLanahan (1985), Keith and Finlay (1985).
} 
the number of students in each class, the number of teachers and the overall school spending is also often included. In a series of reviews on research considering production and efficiency in public schools by Hanushek (1986, 1989, 1996, 1997, 2003) educational inputs are found to be relatively unimportant in explaining student outcomes, and the impact of any particular input has been inconsistent across studies. Krueger (2003) reanalyses the data in Hanushek's reviews and finds that results from literature summaries are critically dependent upon the weight that each study is given and that the literature suggests a positive effect of smaller classes on student achievement. Moreover, there are some recent studies finding effects, both positive and negative, of school variables and this makes it important to control for them. Bonesrønning (2003), for example, in a study based on Norwegian data, finds a negative effect of class size on individual student's school performance.

In the economic literature of education there is large empirical support of the view that the school achievements of a child are not only affected by socioeconomic factors or differences in school quality, but that the peers also play an important role. In fact, the effect of school characteristics is often found to disappear when peer groups are controlled for. ${ }^{5}$ Roberson and Symons (2001) study what determines school achievement at age 11 and the links between the school attainment and earnings at age 33 . They find strong evidence of peer group effects, and state that better peer groups bring up better behaved children.

One of the contributions of this paper is that the empirical analysis, in contrast to most of the previous research in this area, is based upon Swedish data instead of data from the US. The institutional and social environment in Sweden is somewhat different from that in the US. For example, Sweden has a well developed public child care system where most children participate. In addition, it is fairly common for Swedish fathers to take parental leave, and parents often share custody after divorce. Differences of this kind make the analysis interesting.

Another contribution of this paper is the richness of the data. The dataset contains about 50000 individuals and includes a wide variety of socioeconomic variables,

\footnotetext{
${ }^{5}$ See Evans, Oats and Schwab (1992).
} 
enabling control for many aspects that may influence children's educational achievement. Moreover, I have information about the grade point average both when the student graduated from compulsory school and when he or she graduated from upper secondary school. This means that it is possible for me to analyse how the socioeconomic history of the child influences the educational achievements in both compulsory school and in upper secondary school separately. It is also possible to analyse overall effects. However, the most important contribution of this paper, pertaining from the richness of the data, is that the dataset contains labour force participation of both parents, making it possible to test if the labour force participation of fathers is of importance in explaining children's educational achievements.

This paper is based upon a cooperative bargaining model that gives a guideline for the empirical estimations and is presented in section two. The data and descriptive statistics are displayed and discussed in section three and in section four the empirical findings are presented. The paper ends with a concluding summary which is given in section five. 
Among economists, the view of decision-making within the family has varied over time. The traditional approach to study intra-household distribution of demand and supply has been that the household maximizes a single utility function ${ }^{6}$. A newer, and more realistic, view of decision-making within the family is the theory of bargaining, which recognizes that households may not behave as a single decision maker ${ }^{7}$. Pluralistic decision-making can, in turn, be divided into two main categories of models, non-cooperative bargaining models and cooperative bargaining models ${ }^{8}$.

In the non-cooperative models, each spouse maximizes a utility function conditioned on her or his Nash-conjecture about the other spouse's behaviour. The result of such a model is under-provision of the household public good because neither of the spouses takes the other's utility into consideration when they decide how much work to put into home production. Weiss and Willis (1985) suggest that divorced couples might reach this type of inefficient agreement since they are not able to observe each others actions.

In the cooperative bargaining models two spouses maximize an objective that reflects a combination of their utility functions, subject to a single budget constraint for the family. If an agreement is reached, the allocation is Pareto-efficient. Because of the repeated interaction and the fact that spouses are able to monitor each others choices closely it is likely that married couples are able to reach an efficient agreement. It is also likely that the spouses would strive to reach such an agreement because they are both better off if they do. A cooperative bargaining model is the type of model that this empirical analysis is built upon. The theory is not to be tested in this paper but is merely meant to be used as a guideline for how to estimate the production function of the household public good.

\footnotetext{
${ }^{6}$ See for example Samuelson (1956), and Becker (1974).

${ }^{7}$ See for example Manser and Brown (1980), and McElroy and Horney (1981).

${ }^{8}$ See Bergstrom (1997) for a review of how economists view of decision-making within the family has developed over time.
} 
Consider a household with two adult members, $m$ (he) and $f$ (she) and a child. Each household member, $i$, gets utility from three goods: leisure, $L_{i}$, a purely private good, , $C_{i}$, and a household public good to be interpreted as the educational achievements of the child, G. The utility functions of the spouses can be written as:

$$
U^{i}\left(C_{i}, G, L_{i}\right) \quad i=m, f
$$

the utility functions are twice continuously differentiable, strictly concave, and all goods are essential.

Each decision unit allocates his or her total time $T$ between working in the labour market, $l_{i}$, working at home, $t_{i}$, or enjoying leisure. By choosing to work at home, the spouse contributes to the child's educational achievement. The spouses are not by necessity equally productive in providing for the proper care that the child needs to succeed in school and productivity is described by $h_{i}$.

The child's educational achievement is not fully explained by the time that the parents devote or their productivity, but is also depending on some school specific variables, $\mathrm{z}$, and some child specific variables, $x$. This means that the educational achievement of the child will have the following form:

$G_{n}=G\left(t_{m}, t_{f}, h_{m}, h_{f}, z, x, \tilde{G}\right)$

where $\tilde{G}$ contains the socioeconomic characteristics that might influence the educational achievement of the child. These are characteristics related to the child itself, its parents and the school that the child attends. They will be further explained in section three.

Let the productivity in the labour market be described by the exogenously given hourly wage, $w_{i}$. Then private consumption of the spouses can be described by:

$$
\sum C_{i} \leq \sum\left(w_{i} l_{i}+y_{i}\right)
$$


where $y_{i}$ is the exogenously given non-labour income.

The spouses are distinguished from two single individuals on the basis of pooling resources and allocating them jointly. Since the empirical study is based upon historical data, the decision about hours of work in the labour market has already been made. Therefore the household decision problem will be solved contingent on hours of work in the labour market; this allows me to separately study the effect of income and hours of work on the household public good. The decision problem facing the household can be described as follows:

$$
\max _{C_{i}, B, L_{i}, t_{i}} U^{m} U^{f}
$$

subject to: $G=G\left(t_{m}, t_{f}, h_{m}, h_{f}, z, x, \tilde{G}\right)$

$$
\begin{array}{ll}
\sum C_{i} \leq \sum\left(w_{i} l_{i}+y_{i}\right) & \\
T=l_{i}+t_{i}+L_{i} & \text { where } i=m, f
\end{array}
$$

The first restriction is the production function for the household public good, the second restriction is the budget constraint for private consumption and the third restriction is the time constraint.

Solving the above problem will give the equation for time in household production as:

$$
t_{i}=t\left(Y, l_{m}, l_{f}, h_{m}, h_{f}, z, x, \tilde{G}\right) \quad \text { where } Y=\sum\left(w_{i} l_{i}+y_{i}\right) \text { for } i=m, f
$$

Substituting this into the production function for the household public good gives:

$$
G=G\left(Y, l_{m}, l_{f}, h_{m}, h_{f}, z, x, \tilde{G}\right)
$$

which is the equation that will be estimated in this paper. Specifically I will focus on estimating the influence of socioeconomic characteristics on the child's educational achievement. 
The Swedish public school system is made up of nine years of compulsory schooling. After that, students can continue on to two or three years of non compulsory schooling $^{9}$ in the form of upper secondary school, which is something that almost all students in Sweden do (about $95 \%$ in 1994).

This empirical study is based on data covering all students entering upper secondary school ( $10^{\text {th }}$ grade) in 1994 and graduating in 1996 or 1997, depending upon the length of the educational program, (about 50 000) in Sweden. The data has been retrieved from Statistics Sweden (SCB) and contains school information along with socioeconomic characteristics from the 1990 census. The data includes gender, nationality, age, residence, graduating grades from the last year of compulsory school and the last year of upper secondary school, choice of educational-program in secondary school, and information about family structure together with socioeconomic situation. The variables that are included in the empirical analysis in this paper are explained below and descriptive statistics are given in Table 1.

The educational achievement of the child is what I want to estimate. In order to do this, the grades from the last year of compulsory school and the last year of upper secondary school are used as dependent variables in the estimations. The grade from the last year of compulsory school is also included as an explanatory variable in some of the estimations.

The variables used to estimate the influence of socioeconomic characteristics on the child's educational achievement, $\tilde{G}$, are divided into three groups: child related variables, parent related variables and school related variables.

\footnotetext{
${ }^{9}$ These students are the last ones to be able to choose a two year upper secondary education. Now, the upper secondary school in Sweden consist only of different three year educational programs.
} 


\subsection{Child Related Variables}

The child related variables, $x$, consists of child specific characteristics that might influence the child's grade, like gender, immigrant status and if the child has lived through a divorce.

A dummy variable indicating being a second generation immigrant is included since having immigrant parents might affect the grade as, for example, they may have a harder time helping their children with homework. This might be even more obvious in the case of first generation immigrants simply because the parents then have been in Sweden for a shorter time period. In addition, for first generation immigrants, the child itself might also have trouble with the language; therefore, a second dummy is included for this group. A third dummy is included for children born abroad, with Swedish born parents. It is included since this group to a large extent consists of adopted children and they, according to some earlier research ${ }^{10}$, have a harder time succeeding in school.

I have included a single parent household dummy because it is likely that living in dissolved or single parent families is associated with different kinds of problems. Single parents do not have the same resources, in the form of time and money to spend, to provide for their children as do two-parent families. As a consequence, children from single parent households might have disadvantages compared to other children that might affect their achievements.

The child specific variables also include the choice of education program to control for the possibility that teacher ratings differ between educational programs, and that children in different educational programs take different courses. Here, a three year social sciences education in upper secondary school with special interest in social science is used as a reference case.

When it comes to the grades, this data set is somewhat unique. During the schooling of these students, the grading system in Sweden was changed. The students graduated from compulsory school with grades from a norm referenced grading system where

\footnotetext{
${ }^{10}$ See for example Brodzinsky, et. al. (1984).
} 
the "average class" of the nation (riksklass) set the standard. That grading system had a scale from 1 to 5 , with 5 being the highest grade you could get, and 3 representing average achievement. When graduating from upper secondary school, the students are graded according to a criterion referenced system where the focus is to estimate how well the student has met a standardized knowledge criterion instead of comparing the students to the "average class". The new grading system has four levels; fail, pass, pass with distinction and pass with special distinction. This four level scale is then converted into a quantified scale and weighted with course load together with the length of the courses before the grade is positioned on a scale between 0 and 200 .

To take into account the importance of peer group effects, found in previous studies, the average grade of the other students attending the same class is included in later estimations. Peer group can bee influential in different ways, depending on who you are. For example, reasonably good students have a better chance of performing well themselves in a class that performs well on average, other things equal. It can however be hard to interpret the effect of peer groups in empirical papers. The effects can be overestimated due to ambitious parents seeking out the best schools for their children and the peer group variables might instead capture parental influence and ambition $^{11}$.

\subsection{Parent Related Variables}

The parent related variables come from the 1990 census and they consist of total parental income and parental hours of work in the labour market as well as other parent related variables. The other parent related variables are included to control for the parents productivity in the production of the household public good (or the educational achievement of the child), $h_{m}$ and $h_{f}$, since this is not possible to directly observe.

The total labour income variable is likely to have positive effects on the child's grade. For the hours of work in the labour market performed by the parents, the reference case is working full time (35 hours or more). Parents not working at all or working part time, either between 1 and 19 hours or between 20 and 34 hours is then compared

\footnotetext{
${ }^{11}$ Roberson and Symons (2001).
} 
to the reference case. The other parent related variables consist of parental age and a dummy for parental higher education in the form of undergraduate or graduate university studies. The reference case for parental education is compulsory or upper secondary school, which have not been divided into separate dummies since almost all of the parents have graduated from upper secondary school. The parental education dummy is likely to have a positive effect on the child's school achievements.

\subsection{School Related Variables}

The school related variables, $\mathrm{z}$, in the production function of the household public good consist of the average number of students registered in the municipality during the three years of schooling and the average number of teachers per 100 students. The first is meant to capture the effect of living in a larger municipality with larger schools, and larger classes. The second is included since it might have a positive effect on the child's school performance if there are more teachers devoting their time to the child. 
Table 1. Variable explanations and descriptive statistics

\begin{tabular}{|c|c|c|}
\hline Name & Description & Mean \\
\hline \multicolumn{3}{|c|}{ Child related variables } \\
\hline $\begin{array}{l}\text { GPA } 9^{\text {th }} \\
\text { grade }\end{array}$ & $\begin{array}{l}\text { Grade point average, average grade when graduating from } \\
9^{\text {th }} \text { grade compulsory school. Scale } 1-5\end{array}$ & $\begin{array}{l}3,35 \\
(0,63)\end{array}$ \\
\hline $\begin{array}{l}\text { GPA Upp. } \\
\text { sec. }\end{array}$ & $\begin{array}{l}\text { Grade point average, average grade when graduating from } \\
\text { upper secondary school. Scale } 0-200\end{array}$ & $\begin{array}{l}126,47 \\
(26,81)\end{array}$ \\
\hline Male & A dummy that takes the value one if the child is male & 0,50 \\
\hline $\begin{array}{l}\text { Sec. gen. } \\
\text { immigrant }\end{array}$ & $\begin{array}{l}\text { A dummy that takes the value one if the child was born in } \\
\text { Sweden but at least one of the parents was born outside of } \\
\text { Sweden }\end{array}$ & 0,12 \\
\hline $\begin{array}{l}\text { First gen. } \\
\text { immigrant }\end{array}$ & $\begin{array}{l}\text { A dummy that takes the value one if the child as well as at } \\
\text { least one of the parents was born outside of Sweden }\end{array}$ & 0,03 \\
\hline $\begin{array}{l}\text { Child born } \\
\text { abroad }\end{array}$ & $\begin{array}{l}\text { A dummy that takes the value one if the child was born } \\
\text { outside of Sweden but the parents where born in Sweden, } \\
\text { this includes, to a large extent, children that where adopted }\end{array}$ & 0,02 \\
\hline $\mathrm{TT}$ & $\begin{array}{l}\text { A dummy that takes the value one for a two year theoretical } \\
\text { education in upper secondary school }\end{array}$ & 0,08 \\
\hline $\mathrm{TP}$ & $\begin{array}{l}\text { A dummy that takes the value one for a two year practical } \\
\text { education in upper secondary school }\end{array}$ & 0,41 \\
\hline IP & $\begin{array}{l}\text { A dummy that takes the value one for an individual program } \\
\text { in upper secondary school }\end{array}$ & 0,01 \\
\hline $\mathrm{N}$ & $\begin{array}{l}\text { A dummy that takes the value one for a three year natural } \\
\text { sciences education in upper secondary school }\end{array}$ & 0,13 \\
\hline TS & $\begin{array}{l}\text { A dummy that takes the value one for a three year technical } \\
\text { sciences education in upper secondary school }\end{array}$ & 0,7 \\
\hline SBA & $\begin{array}{l}\text { A dummy that takes the value one for a three year social } \\
\text { sciences education in upper secondary school, with special } \\
\text { interest in business administration }\end{array}$ & 0,10 \\
\hline SL & $\begin{array}{l}\text { A dummy that takes the value one for a three year social } \\
\text { sciences education in upper secondary school, with special } \\
\text { interest in languages }\end{array}$ & 0,03 \\
\hline SMC & $\begin{array}{l}\text { A dummy that takes the value one for a three year social } \\
\text { sciences education in upper secondary school, with special } \\
\text { interest in media and communication }\end{array}$ & 0,02 \\
\hline $\begin{array}{l}\text { Average } \\
\text { grade }\end{array}$ & $\begin{array}{l}\text { Average } 9^{\text {th }} \text { grade of the peers in the upper secondary class } \\
\text { there are also a number of interaction dummies with the } \\
\text { educational programs }\end{array}$ & $\begin{array}{c}3,7 \\
(0,27)\end{array}$ \\
\hline Divorce & $\begin{array}{l}\text { A dummy that takes the value one if the child comes from a } \\
\text { single parent household }\end{array}$ & 0,20 \\
\hline
\end{tabular}


Table 1. Continued

\begin{tabular}{|c|c|c|c|}
\hline \multicolumn{2}{|c|}{ Parent related variables } & \multirow{2}{*}{$\begin{array}{c}\text { Mother } \\
39,72 \\
(4,86)\end{array}$} & \multirow{2}{*}{$\begin{array}{c}\text { Father } \\
42,29 \\
(5,50)\end{array}$} \\
\hline Age & $\begin{array}{l}\text { Age of the mother and father respectively in the year of } \\
1990\end{array}$ & & \\
\hline $\begin{array}{l}\text { Higher } \\
\text { education }\end{array}$ & $\begin{array}{l}\text { A dummy that takes the value one if the parent attended } \\
\text { higher education (graduate or undergraduate university } \\
\text { studies) }\end{array}$ & 0,29 & 0,28 \\
\hline $\begin{array}{l}\text { Mother } 0 \\
\text { hours }\end{array}$ & $\begin{array}{l}\text { A dummy that takes the value one if the mother was } \\
\text { unemployed in } 1990\end{array}$ & 0,04 & - \\
\hline $\begin{array}{l}\text { Mother 1-19 } \\
\text { hours }\end{array}$ & $\begin{array}{l}\text { A dummy that takes the value one if the mother worked 1-19 } \\
\text { hours per week in } 1990\end{array}$ & 0,06 & - \\
\hline $\begin{array}{l}\text { Mother 20- } \\
34 \text { hours }\end{array}$ & $\begin{array}{l}\text { A dummy that takes the value one if the mother worked 20- } \\
34 \text { hours per week in } 1990\end{array}$ & 0,43 & - \\
\hline $\begin{array}{l}\text { Father } 0 \\
\text { hours }\end{array}$ & $\begin{array}{l}\text { A dummy that takes the value one if the mother was } \\
\text { unemployed in } 1990\end{array}$ & - & 0,02 \\
\hline $\begin{array}{l}\text { Father 1-19 } \\
\text { hours }\end{array}$ & $\begin{array}{l}\text { A dummy that takes the value one if the father worked 1-19 } \\
\text { hours per week in } 1990\end{array}$ & - & 0,01 \\
\hline $\begin{array}{l}\text { Father 20-34 } \\
\text { hours }\end{array}$ & $\begin{array}{l}\text { A dummy that takes the value one if the father worked 20-34 } \\
\text { hours per week in } 1990\end{array}$ & - & 0,03 \\
\hline $\begin{array}{l}\text { Total } \\
\text { income }\end{array}$ & $\begin{array}{l}\text { Total income, in thousands, of the mother and the father } \\
\text { respectively in the year of } 1990\end{array}$ & $\begin{array}{l}120,64 \\
(74,89)\end{array}$ & $\begin{array}{c}210,54 \\
(227,06)\end{array}$ \\
\hline School relate & d variables & $\begin{array}{l}\text { Comp. } \\
\text { school }\end{array}$ & $\begin{array}{c}\text { Upp. sec. } \\
\text { school }\end{array}$ \\
\hline $\begin{array}{l}\text { Number of } \\
\text { students }\end{array}$ & $\begin{array}{l}\text { Average number of students registered in the municipality } \\
\text { during the three years of upper secondary school and the last } \\
\text { three years of compulsory school respectively }\end{array}$ & $\begin{array}{c}10661,49 \\
(12827,83)\end{array}$ & $\begin{array}{c}4007,34 \\
(4797,28)\end{array}$ \\
\hline $\begin{array}{l}\text { Teacher } \\
\text { density }\end{array}$ & $\begin{array}{l}\text { Average number of teachers per } 100 \text { students in the muni- } \\
\text { cipality during the three years of upper secondary school and } \\
\text { the last three years of compulsory school respectively }\end{array}$ & $\begin{array}{c}8,45 \\
(0,57)\end{array}$ & $\begin{array}{c}7,09 \\
(0,97)\end{array}$ \\
\hline
\end{tabular}

Note: Standard deviations are given parentheses 


\section{$4 \quad$ Empirical Findings}

In this section the empirical findings are presented and analysed. A large number of earlier studies indicate that income pooling does not always give a true description of how a family functions ${ }^{12}$. In line with these studies, a test on the data used in this paper show that the hypothesis of pooling can be rejected ${ }^{13}$ and the total income variable will in the following be separated into two income variables, one for the mother and the father respectively. ${ }^{14}$

In order to analyse the influences of socioeconomic variables on different educational levels, three separate models are estimated. The results are given in Table 2. In the model labelled GPA $9^{\text {th }}$ grade, the grade point average from ninth year of compulsory school is used as a dependent variable. In this model, the influences on of parental work hours on the achievements in compulsory school are analysed. In the second model, that is labelled GPA total, grade point average when graduating from upper secondary school is used as a dependent variable. This model measures the influence of parental work hours on the educational achievements all the way through the upper secondary school. The same dependent variable as in the second model is being used in the third model presented Table 2. What distinguishes the third model from the second is that the grade point average from compulsory school is included in the latter model. Hence, this model separates the additional effects of parental work hours on educational achievements in upper secondary school. Below, the estimation results from the three models will be discussed.

\subsection{Child Related Variables}

As can be seen in Table 2 the signs and significance levels of the coefficients are not changing much ${ }^{15}$ between the three models. In accordance with previous research, male students perform worse than female students both in compulsory and upper

\footnotetext{
12 See for example Fortin and Lacroix (1997).

${ }^{13}$ A t-test performed on a sub-sample including only parents that are married and living together shows that the hypothesis of pooling can be rejected at the 1 percent significance level.

${ }^{14}$ In the theoretical background in this paper, it does not matter who has the income in the family. Despite this shortcoming of the theory, it is still useful since it gives a guideline of which variables to include in the estimations.

${ }^{15}$ The reader should note that the dependent variable in the third model is on a different scale then in the first two models.
} 
secondary school. Having immigrant parents is negative for the upper secondary school grades, but there is no significant effect on the GPA from ninth year of compulsory school. However, being a first generation immigrant has a negative effect on both grades. In addition, children born abroad attain lower grades, on average, than native born children. One might suspect that many of the children in this group are adopted, and the negative coefficient is in line with some previous findings ${ }^{16}$. Furthermore, as in for example McLanahan (1985) and Keith and Finlay (1985), the experience of a separation between the parents is also found to have a negative effect on the child's educational achievements measured both as GPA from upper secondary school as well as GPA from compulsory school.

The coefficients for choice of educational program variables changes drastically between the last two models. When comparing these models, it is clear that students with lower grades are more likely to take part in the TP education, the SMC education or the SBA education. Moreover, students with better grades to a larger extent participate in the $\mathrm{N}$ education or the TS education. When GPA from compulsory school is controlled for, the coefficients for most of the programs change their signs, implying that given your grades from compulsory school it is harder to get good grades in the $\mathrm{N}$ education and in the TS education respectively. One explanation could be that the students in the $\mathrm{N}$ program take other subjects than the students in the S education. For example they take physics, chemistry and more maths. The students choosing the TS education to a large extent take the same classes as do the $\mathrm{N}$ students even though the points required for admission is much lower, this might be the explanation to why they get lower grades.

\subsection{Parent Related Variables}

Both total income and human capital of the parents, measured as number of years of schooling, are variables that frequently are included in studies of children's educational attainment. The two variables are almost always found to be positively associated with the educational achievement of the child. In all three models of Table 2 it can be seen that, when hours of work are controlled for, the child's GPA increases with parents' total income and higher education. The mother's income having a

\footnotetext{
${ }^{16}$ See for example Brodzinsky, et. al. (1984).
} 
positive effect on the child's educational achievement is consistent with the working mother hypothesis. The positive effect of the mother's educational level is larger than that of the father's in the first and second models. This means that for compulsory school grades, the human capital of the mother is more important. This result is in accordance with previous research (e.g. Leibowitz (1974) and Hill and Stafford (1980)). In upper secondary school however, the dominating effect of the mother's human capital has faded and the human capital of the father is now more important. When it comes to parental age, children whose parents where young when their child was born, attain lower grades, on average, than those whose parents where older.

Again, in accordance with the working mother hypothesis, the hours of work performed by mothers seems to be of importance for children's educational achievements. If the mother works part-time when the child is 10-11 years old, especially if working less then halftime, a positive effect on the child's GPA is found. However, having a mother that does not work at all is just as bad as having a mother that works full time. These results are in line with the findings by Stafford (1986). The results are similar in all three models, indicating that the labour market work by mothers is not only important for the compulsory school grades, but that the effects are prevailing into upper secondary school when compulsory school grades are controlled for. Even though the effects are significant, it is important to note that they are small compared to the effect of, for example, higher education.

When it comes to the number of hours worked by the father, they seem to be of minor importance as long as he works. There are, however, negative effects of having a father that does not work at all on the upper secondary school grades. This is interesting since one might expect that variables like these would have a larger impact on the child's earlier grades. There are no other significant effects of the father's hours of work; however, these results should be interpreted with caution. The variation in the hours of work performed by the father is small, almost all of the fathers work full time. If there were more observations of fathers working part time, maybe significant effects could be found. 


\subsection{School Related Variables}

The two grade averages used as dependent variables are increasing with the number of students in the municipality. This implies that students in larger municipalities and hence, in larger schools perform better than students in for example the countryside. Both grades are also increasing with the number of teachers per 100 students which is not surprising. The effects are however quite small, especially from the number of students.

\subsection{Peer Group Effects}

Even though the results seem to be reasonably non sensitive to the three different specifications, a further sensitivity check might be called for since peer group effects previously have been found to be of importance when explaining educational achievement. Therefore three models that include peer variables are estimated. The results of these regressions are given in Appendix, Table 3. In order to analyse peer group effects, the sample is changed dramatically with the number of observations decreasing from 50000 to about 7000 . This is due to the fact that it is not possible to identify individual classes in the two year educations and in the individual programs. The estimations only include three year educational programs and only students at fairly small schools since it is not possible to see which students that belong to which class at the larger schools. The population is hence somewhat different form the previous one in the sense of being more homogenous. The first two models investigate the effects on upper secondary school only; while model three investigate total effects. In Table 3 there is also a fourth model included. In that model the same type of regression as in the third model in Table 2 is done, but with the same sample as in the GPA models.

At first glance, it looks at though when peer groups are taken into account, the coefficients change drastically. Turning to the fourth model though, this seems not to be due to the peer group variables being included but to the homogeneity of the sample.

For upper secondary school, I loose the significance of being first or second generation immigrant, of divorce, and the age of the parents no longer seem to matter. 
Being born abroad, however, still has a negative impact on GPA. Parental education and income are both still significant and positive. When looking at the overall effects though, the coefficients are very much like the ones in table 2 . The exception is the coefficients for parental age which are not significant.

An interesting thing is that for the upper secondary school grades, when compulsory school grades are controlled for, boys are performing better. In the third model, the effect is the same as in the Table 2 regressions, meaning that the overall effect of being male is still negative for the grades.

The hours of work by the parents doesn't seem to matter when looking at upper secondary school grades only for this reduced sample. But if the mother works less than full time it again has positive overall effects on the child's grade. Interestingly enough, in this sample, it has positive overall effects if the father works less than full time, but more than halftime. This implies the existence of a working father hypotesis.

When looking at the upper secondary school grades only, in the first and second models, the effect of the average grade variable is negative, meaning that, given your compulsory school grades, attending a class with better students is negative (see section 3.1). The exception is if you are studying the three year natural science program, then it is positive if your peers are performing well. Looking at overall effects, in the third model, the average grade coefficient is instead positive, this is in line with earlier research.

The coefficient for the number of students is no longer significant in any of the models, which is not surprising since all students included in this sample attend small schools and schools tend to be smaller in smaller municipalities. The teacher density has an effect on the upper secondary school grades, but the number of upper secondary school teachers has no overall effect. To sum up, the inclusion of the peer group effect variables does not seem to offset the effects of school specific variables here. 
Table 2. Estimation results

\begin{tabular}{|c|c|c|c|}
\hline \multirow[b]{2}{*}{ Variable } & \multicolumn{3}{|c|}{ Model } \\
\hline & GPA $9^{\text {th }}$ grade & GPA total & GPA upp. sec. \\
\hline Constant & $2,88^{* * *}$ & $114,56^{* * *}$ & $-3,77 * * *$ \\
\hline GPA $9^{\text {th }}$ grade & - & - & $33,51^{* * *}$ \\
\hline Male & $-0,25 * * *$ & $-8,84 * * *$ & $-1,13^{* * *}$ \\
\hline Sec. gen. immigrant & $4,0 \mathrm{E}-03$ & $-2,28 * * *$ & $-1,23^{* * *}$ \\
\hline First gen. immigrant & $-0,12 * * *$ & $-9,06 * * *$ & $-3,48 * * *$ \\
\hline Child born abroad & $-0,34 * * *$ & $-12,81 * * *$ & $-5,85 * * *$ \\
\hline TT & - & $-0,24$ & $5,65^{* * *}$ \\
\hline TP & - & $-8,90 * * *$ & $10,16^{* * *}$ \\
\hline IP & - & $-38,67 * * *$ & $-5,71^{* * *}$ \\
\hline $\mathrm{N}$ & - & $14,40 * * *$ & $-4,4 \mathrm{E}-02$ \\
\hline TS & - & $5,92 * * *$ & $-3,51^{* * *}$ \\
\hline SBA & - & $-1,41 * * *$ & $-0,17$ \\
\hline SL & - & $8,33^{* * *}$ & $4,85^{* * *}$ \\
\hline SMC & - & $-4,26 * * *$ & $2,87^{* * *}$ \\
\hline Divorce & $-9,3 \mathrm{E}-02 * * *$ & $-2,88 * * *$ & $-1,18^{* * *}$ \\
\hline Mother age & $6,1 \mathrm{E}-03 * * *$ & $0,15^{* * *}$ & $0,11^{* * *}$ \\
\hline Father age & 1,3E-03* & $0,14^{* * *}$ & $0,11^{* * *}$ \\
\hline Mother higher education & $0,24 * * *$ & $5,17^{* * *}$ & $2,11^{* * *}$ \\
\hline Father higher education & $0,21^{* * *}$ & $4,45^{* * *}$ & $2,84^{* * *}$ \\
\hline Mother 0 hours & $-1,3 \mathrm{E}-03$ & $-0,55$ & $-0,38$ \\
\hline Mother 1-19 hours & $3,9 \mathrm{E}-02 * * *$ & $2,72^{* * *}$ & $1,46^{* * *}$ \\
\hline Mother 20-34 hours & $6,3 \mathrm{E}-02 * * *$ & $2,28 * * *$ & $0,86^{* * *}$ \\
\hline Father 0 hours & $-2,3 \mathrm{E}-02$ & $-1,79 * *$ & $-1,47^{* *}$ \\
\hline Father 1-19 hours & $-2,4 \mathrm{E}-02$ & $-0,64$ & 0,12 \\
\hline Father 20-34 hours & $-1,3 \mathrm{E}-02$ & 0,78 & 0,52 \\
\hline Mother total income & $4,8 \mathrm{E}-04 * * *$ & $1,1 \mathrm{E}-02 * * *$ & $6,4 \mathrm{E}-03^{* * *}$ \\
\hline Father total income & $1,7 \mathrm{E}-04 * * *$ & $2,8 \mathrm{E}-03 * * *$ & $3,6 \mathrm{E}-03^{* * *}$ \\
\hline Number of students & $1,2 \mathrm{E}-06^{* * *}$ & $1,4 \mathrm{E}-04 * * *$ & $4,8 \mathrm{E}-05^{* *}$ \\
\hline Teacher density & $9,4 \mathrm{E}-03^{* *}$ & $0,20 * *$ & $0,37^{* * *}$ \\
\hline $\mathrm{R}^{2}$ adjusted & 0,16 & 0,21 & 0,54 \\
\hline Number of observations & 48889 & 49033 & 48880 \\
\hline
\end{tabular}

* Statistically Significant at the 10 percent level

** Statistically Significant at the 5 percent level

*** Statistically Significant at the 1 percent level 


\section{$5 \quad$ Conclusions}

This paper examines the effects of parental hours of work on children's educational achievement measured both as GPA from ninth year of compulsory school and as GPA from the last year of upper secondary school while controlling for a wide range of socioeconomic variables. The empirical part is based upon data about almost all of the students graduating from upper secondary school in 1997 (about 50000 individuals). The main findings are that, in line with the working mother hypothesis and with previous research, there is a positive effect of the mother's income (contingent on hours of work) on the child's performance in school. A higher income by fathers is also associated with higher GPA among children. The hours of labour market work by mothers' influences the educational achievements of the children. If the mother works less then full time, preferably even less then halftime, it has positive effects on the child's grades. The effects are not only found in compulsory school, but are also appearing when upper secondary school is singled out. This is also in line with the working mother hypothesis and in line with previous studies by for example Stafford (1986). There are no significant effects of the father's hours of work, as long as he works a positive amount of time. The reason for this result may, however, be that there is to little variation in the hours of work performed by fathers, and should thereby be interpreted with caution. 


\section{Appendix}

Table 3. Estimation results with peers

\begin{tabular}{|c|c|c|c|c|}
\hline \multirow[b]{2}{*}{ Variable } & \multicolumn{4}{|c|}{ Model } \\
\hline & GPA peer group & $\begin{array}{c}\text { GPA peer grou } \\
\text { without } \\
\text { interactions }\end{array}$ & $\begin{array}{l}\text { GPA peer group } \\
\text { total }\end{array}$ & $\begin{array}{c}\text { GPA same } \\
\text { sample as peer }\end{array}$ \\
\hline Constant & $-5,49$ & $-15,23 * *$ & $71,02 * * *$ & $-35,63 * * *$ \\
\hline GPA $9^{\text {th }}$ grade & $41,97 * * *$ & $41,87 * * *$ & - & $41,56^{* * *}$ \\
\hline Male & $0,88^{*}$ & $0,86^{* *}$ & $-7,84^{* * *}$ & $0,91^{*}$ \\
\hline Sec. gen. immigrant & $-0,61$ & $-0,60$ & $-16,46^{* * *}$ & $-0,62$ \\
\hline First gen. immigrant & $-1,52$ & $-1,45$ & $-3,23 * * *$ & $-1,50$ \\
\hline Child born abroad & $-6,54 * * *$ & $-6,53 * * *$ & $-6,77 * * *$ & $-6,54 * * *$ \\
\hline $\mathrm{N}$ & $-57,40 * * *$ & $-1,93^{* *}$ & $9,37 * * *$ & $-4,22 * * *$ \\
\hline TS & $-13,33$ & $-4,41 * * *$ & $4,51^{* * *}$ & $-5,51 * * *$ \\
\hline SBA & $-12,38$ & 0,75 & 0,70 & 1,09 \\
\hline SL & $-26,59$ & $4,62 * * *$ & $6,57 * * *$ & $3,92 * * *$ \\
\hline SMC & 16,60 & $3,33 * *$ & $-2,29$ & $5,04 * * *$ \\
\hline Average grade & $-8,74 * *$ & $-5,79 * * *$ & $11,75^{* * *}$ & - \\
\hline Average grade * $\mathrm{N}$ & $14,15^{* *}$ & - & - & - \\
\hline Average grade $*$ TS & 2,51 & - & - & - \\
\hline Average grade * SBA & 3,68 & - & - & - \\
\hline Average grade * SL & 8,50 & - & - & - \\
\hline Average grade * S MC & $-4,30$ & - & - & - \\
\hline Divorce & $-0,87$ & $-0,95$ & $-2,36^{* *}$ & $-0,92$ \\
\hline Mother age & 0,12 & 0,11 & 0,16 & 0,11 \\
\hline Father age & $8,1 \mathrm{E}-02$ & $7,8 \mathrm{E}-02$ & 0,12 & 7,7E-02 \\
\hline Mother higher education & $1,92^{* * *}$ & $1,91^{* * *}$ & $5,26^{* * *}$ & $1,91^{* * *}$ \\
\hline Father higher education & $2,54^{* * *}$ & $2,49 * * *$ & $4,43^{* * *}$ & $2,46^{* * *}$ \\
\hline Mother 0 hours & $-0,84$ & $-1,05$ & $-2,51$ & $-1,10$ \\
\hline Mother 1-19 hours & 1,08 & 1,03 & $3,79 * * *$ & 1,00 \\
\hline Mother 20-34 hours & 0,69 & 0,67 & $2,01^{* * *}$ & 0,68 \\
\hline Father 0 hours & $-2,38$ & $-2,4$ & $-4,11$ & $-2,30$ \\
\hline Father 1-19 hours & 3,96 & 3,8 & 2,17 & 3,73 \\
\hline Father 20-34 hours & 1,90 & 2,03 & $3,45^{*}$ & 2,09 \\
\hline Mother total income & $8,1 \mathrm{E}-04 * * *$ & $8,0 \mathrm{E}-04 * * *$ & $1,4 \mathrm{E}-03 * * *$ & $7,9 \mathrm{E}-04 * * *$ \\
\hline Father total income & $4,7 \mathrm{E}-04 * * *$ & $4,7 \mathrm{E}-04 * * *$ & $1,6 \mathrm{E}-04 * * *$ & $4,8^{* * *} \mathrm{E}-04$ \\
\hline Number of students & 2,6E-05 & 2,8E-05 & 8,6E-05 & 2,7E-05 \\
\hline Teachers & $0,63^{* *}$ & $0,61^{* *}$ & 0,42 & $0,73^{* *}$ \\
\hline $\mathrm{R}^{2}$ adjusted & 0,56 & 0,56 & 0,15 & 0,56 \\
\hline Number of observations & 6308 & 6313 & 6314 & 6314 \\
\hline
\end{tabular}

* Statistically Significant at the 10 percent level

** Statistically Significant at the 5 percent level

*** Statistically Significant at the 1 percent level 


\section{References}

Becker, G. (1974), “A theory of social interactions”, Journal of Political Economy, Vol. 82 (6), pp. 1063-1094.

Bergstrom, T.C., (1997), “A Survey of Theories of the Family”, (red.) Rosenzweig, M.R., Stark, O. Handbook of Population and Family Economics, Vol. 1A, NorthHolland, Amsterdam

Bonesrønning, H. (2003), “Class Size Effects on Student Achievement in Norway: Patterns and Explanations”, Southern Economic Journal, Vol. 69 (4), pp. 952-965.

Brodzinsky, D.M., Schechter, D.E., Braff, A.M. and Singer, L.M., (1984), "Psychological and academic adjustment in adopted children”, Journal of Consulting and Clinical Psychology, Vol. 52, pp. 582-590.

Datcher-Loury, L. (1988), “Effects of Mother's Home Time on Children's Schooling”, The Review of Economics and Statistics, Vol. 70 (3), pp. 367-373.

Evans, W. N., Oats, W. E., and Schwab, R. M. (1992), “Measuring Peer Group Effects: A Study of Teenage Behaviour”, Journal of Political Economy, Vol. 100 (5), pp. 966-991.

Fortin, B. and Lacroix, G. (1997), “A test of the Unitary and Collective Models of Household Labour Supply”, The Economic Journal, Vol. 107 (443), pp. 933-955.

Hanushek, E. A. (1986),” The Economics of Schooling: Production and Efficiency in Public Schools”, Journal of Economic Literature, Vol. 24 (September), pp. 11411177.

Hanushek, E. A. (1989), “Expenditure, efficiency and equity in education: the federal government's role”, American Economic Review, Vol. 79 (2), pp. 46-51. 
Hanushek, E. A. (1996), “School resources and student performance”, In Does Money Matter? The Effect of School Resources on Student Achievement and Adult Success, pp. 43-73, edited by G. Burtless, Washington DC, Brookings Institution.

Hanushek, E. A. (1997), “Assessing the effects of school resources on student performance: an update”, Education Evaluation and Policy Analysis, Vol. 19 (2), pp. 141-164.

Hanushek, E. A. (2003), “The failure of input-based schooling policies”, The Economic Journal, Vol. 113 (February), pp. F68-F98.

Haveman, R., Wolfe, B., and Spaulding, J. (1991), “Childhood Events and Circumstances Influencing High School Completion”, Demography, Vol. 28 (1), pp.133-157.

Hetherington, E.M, Camara K. A., and Featherman D. L. (1983), “Achievement and Intellectual Functioning of Children in One-Parent Households”, In Achievement and Achievement Motives: Psychological and Sociological Approaches, edited by J., Spence. San Francisco, Freeman.

Hill, C. R. and Stafford F. P. (1980), "Parental Care of Children: Time Diary Estimates of Quantity, Predictability, and Variety”, Journal of Human Resources, Vol. 15 (2) pp. 219-239.

Hill, M. S. and Duncan, G. (1987), "Parental Family Income and the Socioeconomic Attainment of Children”, Social Science Research, Vol. 16 (1), pp. 39-73.

Keith, V. and Finlay, B. (1988), “The impact of Parental Divorce on Children's Educational Attainments, Marital Timing, and Likelihood of Divorce”, Journal of Marriage and the Family, Vol. 50 (3), pp. 797-809.

Krueger, A. B., “Economic consideration and class size”, The Economic Journal, Vol. 113 (February), pp. F34-F63. 
Leibowitz, A. (1977), “Parental Inputs and Children's Achievement”, Journal of Human Resources, Vol. 12 (2), pp. 242-251.

Manser, M. and Brown, M. (1980),"Marriage and household decision theory - a bargaining analysis”, International Economic Review, Vol. 21 (1), pp. 21-34.

McElroy, M. and Horney, M. (1981), "Nash-bargained decisions: toward a generalization of the theory of demand”, International Economic Review, Vol. 22 (2), pp. 333-349.

McLanahan, S. (1985), "Family structure and the reproduction of poverty”, American Journal of Sociology, Vol. 90 (4), pp. 873-901.

Murnane, R. J., Maynard, R. A. and Ohls, J.C. (1981), "Home Resources and Children's Achievement”, The Review of Economics and Statistics, Vol. 63 (3), pp. 369-77.

Pribesh, S. and Downey, D. B. (1999), "Why Are Residential and School Moves Associated with Poor School Performance”, Demography, Vol. 36 (4), pp. 521-534.

Roberson, D. and Symons, J. (2001), “Do Peer Groups Matter? Peer Group versus Schooling Effects on Academic Attainment, Economica, Vol. 70 (277), pp. 31-53

Samuelson, P. (1956), “Social indifference curves”, Quarterly Journal of Economics, Vol. 70 (1), pp. 1-22.

Stafford, F. P. (1986), “Woman’s Work, Sibling Competition, and Children’s School Performance”, American Economic Review, Vol. 77 (5), pp. 972-80.

Weiss Y. och R.J. Willis, (1985), “Children as Collective Goods and Divorce Settlements”, Journal of Labour Economics, Vol. 3 (3), pp. 268-92.

Widmalm, F. (2000), “Studies in Growth and Household Allocation”, Economic studies 48, Department of Economics, Uppsala university. 